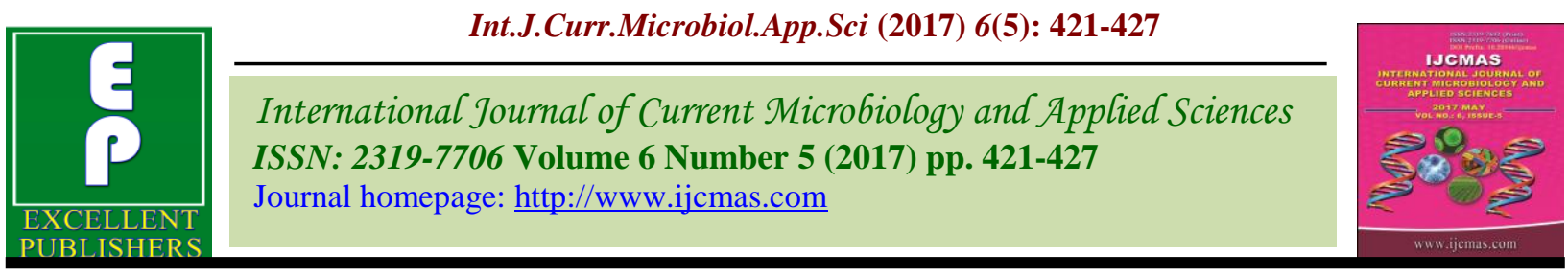

Original Research Article https://doi.org/10.20546/ijcmas.2017.605.048

\title{
In vitro Evaluation of Various Fungicides and Plant Extracts against Xanthomonas oryazae pv. oryzae Isolated from Rice (Oryza sativa L.)
}

\author{
Archana Bala ${ }^{1}$, Bimla Rai ${ }^{1}$, Sweta Priya ${ }^{1}$ and Rahul Kumar ${ }^{2} *$ \\ ${ }^{1}$ Dr. Rajendra Prasad Central Agricultural University, Pusa, Samastipur, Bihar, India - 848125 \\ ${ }^{2}$ ICAR Research Complex for Eastern Region Patna, Bihar, India - 800014 \\ *Corresponding author
}

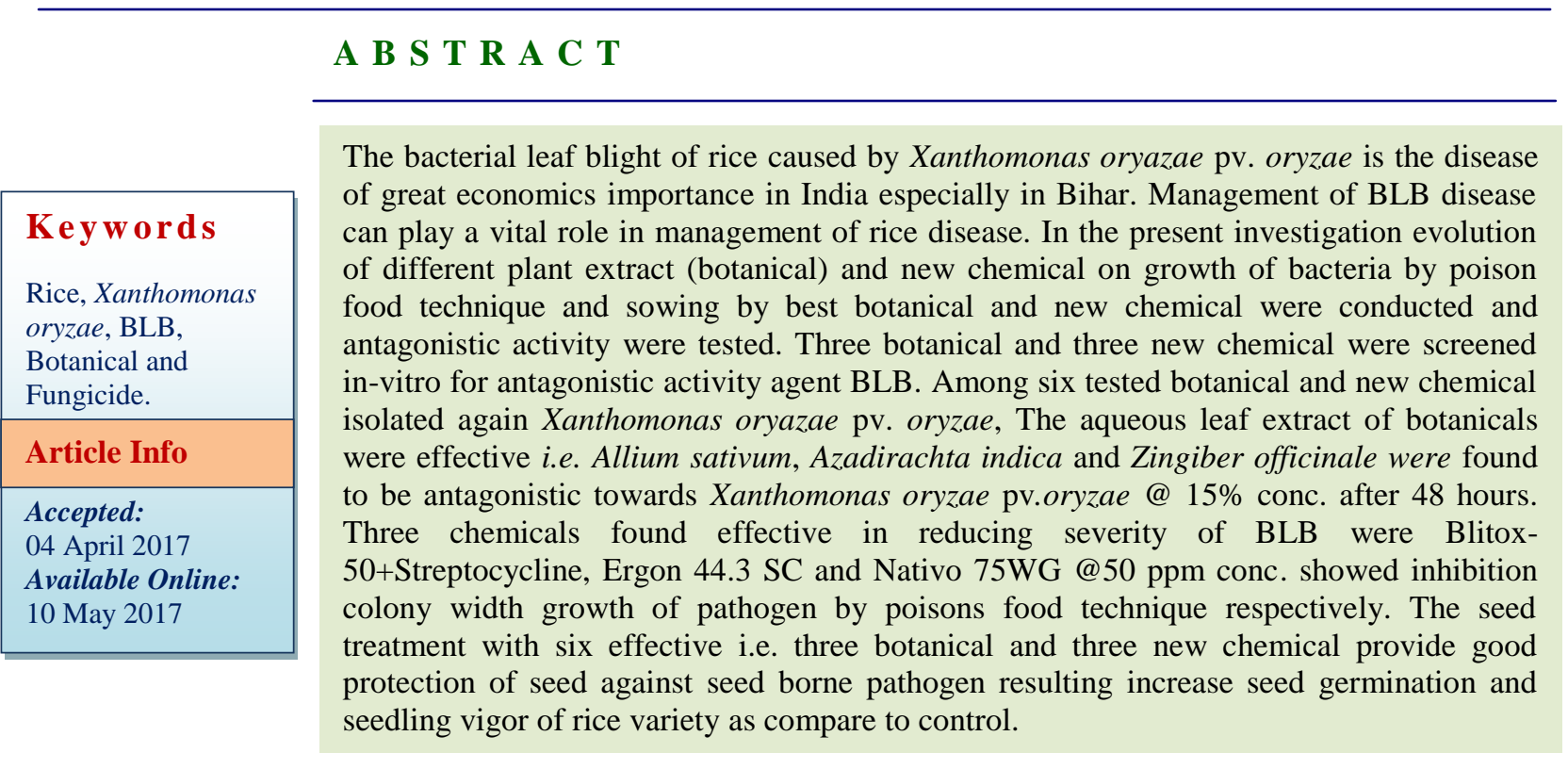

\section{Introduction}

Bacterial leaf blight of rice caused by Xanthomonas oryzae pv. oryzae (Ishiama) Swing et al., (1990) is the disease of great economic in India (Bihar). BLB disease prevost in almost all the paddy growing region in the state, it is considered to be a major constraint for low rice productivity in India (Bihar). It was first reported from India by Srinivasm et al., (1959)) from Maharashtra. It is typical vascular disease, systemic in nature. The disease causes infection at nursery seedling after transplanting and later at booting or heading stage. Its Kresek phase is long lasting and destructive phase. Some of the chemical are effective against this disease but they have not proved economical and harmful residues in soil and plant. Earlier investigation was planned to manage the disease with the help of botanical and new chemical which have antagonistic bacterial activity. Antagonistic activity of botanical and new chemical was judged against premising isolates of BLB by Nutrient Agar well plated method (Manav and Thind, 2002). Botanical and new chemical control of BLB can play a vital role in 
management rice disease (Singh et al., 2010). In the present investigation, different botanical and new chemical were control by poison food technique and sowing of most efficient botanical and new chemicals were conducted and tested the antagonistic activity against the BLB pathogen Xanthomonas oryzae pv. oryzae.

There are also some reports that seed treatment with botanical and new chemicals influences the germination of seed and growth of seedling in several crops (Sen, 1999, Biswas et al., 2008). Therefore, the present study was undertaken to find out the activity of botanicals and new chemicals isolates as seed treatment on seed germination four rice variety i.e. Pusa Basmati.

\section{Materials and Methods}

\section{Isolation and identification of causal organism}

The leaves from the diseased plants were collected from the field and cut into small pieces along with healthy portion. Cut pieces were sterilized by the surface disinfectants e.g. $0.1 \%$ mercuric chloride for 30 seconds. After sterilization the cut pieces were washed three times with sterile water.

The cut pieces were then placed on sterile blotter paper to remove excess water. The cut pieces were then placed on the Nutrient Agar plate. The plate were labelled and placed in the incubation chamber for 7 days at $25+2^{\circ}$ C. After 7 days of incubation, the fungi grown on culture media. In bacterial leaf blight causal organism Xanthomonas oryzae isolated on nutrient Agar media. A portion of culture was taken by inoculating needle on nutrient Agar media plates. The pathogen, thus purified, was kept in refrigerator for future use. All these operations were done aseptically in the laminar air flow chamber.
Evaluations of various plant extracts and new chemicals on growth of bacteria by poisoned food technique

All the plant materials of five plant species tested for their antibacterial activity were collected from surrounding area, RAU, Pusa, Samastipur (Bihar), India. Fresh leaves i.e. Calendula officinalis, Ocimum tenuiflorum and Azadirachta indica, cloves Allium sativum and rhizome Zingiber officinale of five different plants were evaluated against BLB to examine their inhibitory efficacy on growth of the bacteria. All botanical leaf plant were collected and washed 3-5 times by tap water than after washed with distilled water, processed with sterile distilled water at 1:2 ratio viz: $1 \mathrm{~g}$ tissue in $2 \mathrm{ml}$ water then grinding in mixing grinder, each of separately then filtered with muslin cloth. Filtered was centrifuged at $1000 \mathrm{spm}$ for $15 \mathrm{~min}$. and clear supernatants was collected. The supernatant was filtered, sterilized to avoid contamination. The obtained extract formed the standard extract solution.

\section{New chemical}

Nativo (Trifloxystobin + Tebuconozole), Ergon (Kerosim methyl), Mirador (Azoxystrobin) and Blitox-50 (Copperoxychloride) + Streptocycline. Four concentration of each chemical i.e. 10 ppm, $25 \mathrm{ppm}$ and $50 \mathrm{ppm}$ were used against the pathogen.

To obtain desired concentration of botanical extract and new chemical in the medium on amount of stock solution to be added in NA (Nutrient agar) medium. The all material were incorporated into NA medium at desire concentration. The amended NA was poured into $20 \mathrm{~mm}$ sterilized petriplated under aseptic condition in inoculums chamber @ $20 \mathrm{ml}$ medium/plate and NA without leaf extract and new fungicide served as control 
and allowed to solidify. All petriplates were inoculated a loop full of $48 \mathrm{hrs}$. old Xanthomonas oryzae pv. oryzae culture were streaked on these prepared plates and kept for incubation at 28.c for 72 hrs. After incubation, the observations were recorded on the growth of Xanthomonas oryzae pv. oryzae. on different concentration. Based on observation, \% inhibition was calculated by following formula.

$$
\begin{aligned}
& \text { Percentage Inhibition (PI) }=\frac{C-T}{C} \times 100 \\
& \mathrm{C}=\text { Radial growth of pathogen in } \\
& \text { control plate. } \\
& \mathrm{T} \quad=\text { Radial growth of pathogen in dual } \\
& \text { culture }
\end{aligned}
$$

Effect of seed treatment with most efficient botanical and new chemical in vitro was done

The seed were socked with botanical extracts and new chemical (i.e. effective against the BLB pathogen). Seed of variety i.e. Pusa Basmati were soaked with botanical and new chemical and grown in sterillized petriplates. Incubate the plate initially for $24 \mathrm{hrs}$. under controlled condition in growth chamber. Five replicates of 25 seeds were maintained for each treatment, while distilled water treated served as control.

\section{Results and Discussion}

We tested five different plant species for antibacterial activity of bacterial leaf blight pathogen. All the five aqueous botanicals extracts i.e. Calendula officinalis, Ocimum tenuiflorum, Zingiber officinale, Azadirachta indica and Allium sativum inhibit the growth of Xanthomonas oryzae pv.oryzae as compare to control in all the three concentrations i.e. 5, 10 and $15 \%$. The effect of plant extracts increases with increase in concentration of plant extracts.
When compared with out of five botanicals after 48 hours of incubation Allium sativum (87.33\%), Azadirachta indica ((71.23\%) and Zingiber officinale $(60.83 \%)$ were found to be antagonistic towards Xanthomonas oryzae pv.oryzae @ 15\% conc. after 48 hours. Narasimhan et al., (1995) and Kagle et al., (2004) have reported antibacterial activity and management of bacterial diseases with use of different plant extracts in other crops. Kumar et al., (2009) also reported that at $25 \%$ concentration minimum number of colonies development were observed in case of Allium sativum (18.67) which showed maximum inhibition i.e. $41.06 \%$, Present finding also similar with the findings of Kagale et al., (2004), Meena and Gopalakrishnan (2004) and Sunder et al., (2005). They also reported the inhibitory effect of Azadirachta indica and Zingiber officinale against Xathomonas oryzae pv. oryzae.

\section{Evaluation of different new chemicals against Xanthomonas oryzae pv. oryzae}

An experiment was conducted the effect of four new chemicals namely Nativo $75 \mathrm{WG}$, Blitox-50+Streptocycline, Mirador and Ergon 44.3 SC @10ppm, 25ppm and 50ppm by poisoned food technique. The colony width growths of the pathogen were recorded after 48 hrs. at $27^{\circ} \mathrm{C}$.

When compared with all new chemicals after 48 hours of incubation Blitox-50+ Streptocycline (70.25\%), Ergon 44.3 SC (66.4\%), Nativo 75WG (49.91\%) and Mirador (35.33\%) which against Xanthomonas oryzae pv. oryzae. \%). Patel et al., (2009) concerned that Blitox-50 is superior treatment for reducing Bacterial leaf blight intensity and incur grain and show yield and it is highly effective. Where also same reported by previous worker (Munna et al., 2009 and Thimmegowda. 
The most efficient botanical (Plant leaf extract) and new chemical will be evaluated for seed treatment (germination) of rice

Seed treatment with these three plant extracts Allium sativum, Azadirachta indica and Zingiber officinale Neem, effective against the Xanthomonas oryzae pv. oryzae were tested for seed germination of rice through seed treatment on variety i.e. Pusa Basmati @ different conc. i.e. $5 \%, 10 \%$ and $15 \%$ after 48 hours. Aqueous leaf/bulb/cloves extracts@of different plants were increased the shoot length of rice variety. Seed treatment with Zingiber officinale, Azadirachta indica and Allium sativum @ 15\% conc. resulted in 88\%, $85 \%$ and $72 \%$ germination respectively.

Allium sativum, Azadirachta indica and Zingiber officinale enhanced the root and shoots length and seed germination in cv. Pusa Basmati. Kagle et al., (2004), Kumar et al., (2009) and Narasimhan et al., (1995) recommended the use of garlic, ginger as well as neem in order to get high germination and control seed borne bacteria.

Table.1 In vitro effect of different aqueous extracts of botanicals on the growth of Xanthomonas oryzae pv. Oryzae

\begin{tabular}{|c|c|c|c|c|c|c|}
\hline \multirow[t]{2}{*}{ Treatment } & \multicolumn{2}{|c|}{$5 \%$ Concentration } & \multicolumn{2}{|c|}{$10 \%$ Concentration } & \multicolumn{2}{|c|}{$15 \%$ Concentration } \\
\hline & $\begin{array}{c}\text { Bacterial } \\
\text { Growth } \\
\text { colony } \\
\text { width } \\
(\mathrm{mm}) *\end{array}$ & $\begin{array}{c}\text { Per cent } \\
\text { inhibition } \\
\text { over } \\
\text { control }\end{array}$ & $\begin{array}{c}\text { Bacterial } \\
\text { Growth } \\
\text { colony } \\
\text { width } \\
(\mathrm{mm}) *\end{array}$ & $\begin{array}{l}\text { Per cent } \\
\text { inhibition } \\
\text { over } \\
\text { control }\end{array}$ & $\begin{array}{l}\text { Bacterial } \\
\text { Growth } \\
\text { colony } \\
\text { width } \\
(\mathrm{mm}) *\end{array}$ & $\begin{array}{c}\text { Per cent } \\
\text { inhibition } \\
\text { over } \\
\text { control }\end{array}$ \\
\hline $\begin{array}{l}\text { Calendula } \\
\text { officinalis } \\
\text { (Marigold) }\end{array}$ & 16.375 & 45.42 & 12.025 & 59.92 & 11.325 & 62.25 \\
\hline $\begin{array}{l}\text { Ocimum } \\
\text { tenuiflorum (Tulsi) }\end{array}$ & $15.025 \mathrm{a}$ & 49.92 & 11.663 & 61.12 & 11.250 & 62.50 \\
\hline $\begin{array}{l}\text { Zingiber officinale } \\
\text { (Ginger) }\end{array}$ & 12.900 & 57.00 & 12.125 & 59.58 & 11.750 & 60.83 \\
\hline $\begin{array}{l}\text { Azadirachta indica } \\
(\text { Neem) }\end{array}$ & 12.375 & 58.75 & 9.200 & 69.33 & 8.625 & 71.25 \\
\hline $\begin{array}{l}\text { Allium } \quad \text { sativum } \\
\text { (Garlic) }\end{array}$ & 8.300 & 72.33 & 5.050 & 83.17 & 3.800 & 87.33 \\
\hline Control & \multicolumn{2}{|c|}{30.000} & \multicolumn{2}{|c|}{30.000} & \multicolumn{2}{|c|}{30.000} \\
\hline$C D @ 5 \%$ & \multicolumn{2}{|c|}{1.070} & \multicolumn{2}{|c|}{1.536} & \multicolumn{2}{|c|}{1.502} \\
\hline$C V \%$ & \multicolumn{2}{|c|}{4.517} & \multicolumn{2}{|c|}{7.690} & \multicolumn{2}{|c|}{7.843} \\
\hline
\end{tabular}


Table.2 In vitro effect of different new chemicals on the growth of Xanthomonas oryzae pv. Oryzae

\begin{tabular}{|c|c|c|c|c|c|c|}
\hline \multirow[t]{2}{*}{ Treatment } & \multicolumn{2}{|c|}{10 ppm } & \multicolumn{2}{|c|}{25 ppm } & \multicolumn{2}{|c|}{50 ppm } \\
\hline & $\begin{array}{l}\text { Bacterial } \\
\text { Growth } \\
\text { colony } \\
\text { width } \\
(\mathrm{mm})^{*}\end{array}$ & $\begin{array}{l}\text { Per cent } \\
\text { inhibition } \\
\text { over } \\
\text { control }\end{array}$ & $\begin{array}{l}\text { Bacterial } \\
\text { Growth } \\
\text { colony } \\
\text { width } \\
(\mathrm{mm})^{*}\end{array}$ & $\begin{array}{l}\text { Per cent } \\
\text { inhibition } \\
\text { over } \\
\text { control }\end{array}$ & $\begin{array}{l}\text { Bacterial } \\
\text { Growth } \\
\text { colony } \\
\text { width } \\
(\mathrm{mm})^{*}\end{array}$ & $\begin{array}{c}\text { Per cent } \\
\text { inhibition } \\
\text { over } \\
\text { control }\end{array}$ \\
\hline $\begin{array}{l}\text { Nativo } \\
\text { (Trifloxystrobin } \\
\text { 25\%+Tebuconozole } 50 \% \text { ) }\end{array}$ & 18.375 & 38.75 & 16.675 & 44.41 & 15.025 & 49.91 \\
\hline $\begin{array}{l}\text { Blitox-50 (Copper } \\
\text { oxycloride+Streptocycline) }\end{array}$ & 11.000 & 63.33 & 10.375 & 65.41 & 8.925 & 70.25 \\
\hline Mirador (Azoxystobin) & 22.425 & 25.25 & 21.475 & 28.42 & 19.400 & 35.33 \\
\hline $\begin{array}{l}\text { Ergon 44.3 SC (Kreosim } \\
\text { methyle) }\end{array}$ & 14.175 & 52.75 & 13.700 & 54.33 & 10.075 & 66.41 \\
\hline CONTROL & \multicolumn{2}{|c|}{30.000} & \multicolumn{2}{|c|}{30.000} & \multicolumn{2}{|c|}{30.000} \\
\hline$C D @ 5 \%$ & \multicolumn{2}{|c|}{2.038} & \multicolumn{2}{|c|}{1.203} & \multicolumn{2}{|c|}{1.640} \\
\hline$C V \%$ & \multicolumn{2}{|c|}{6.980} & \multicolumn{2}{|c|}{4.288} & \multicolumn{2}{|c|}{6.463} \\
\hline
\end{tabular}

Table.3 Effect of Plant extract as seed treatment on seed germination of rice

\begin{tabular}{|l|c|c|c|c|c|c|c|c|c|}
\hline \multirow{2}{*}{$\begin{array}{c}\text { Plant } \\
\text { Extract }\end{array}$} & \multicolumn{2}{|c|}{$\mathbf{5 \%}$ Concentraton } & \multicolumn{2}{c|}{$\mathbf{1 0} \%$ Concentration } & \multicolumn{3}{c|}{$\mathbf{1 5} \%$ Concentration } \\
\cline { 2 - 10 } & $\begin{array}{c}\text { Germinat } \\
\text {-ion*\% }\end{array}$ & $\begin{array}{c}\text { Shoot } \\
\text { length } \\
* \\
(\mathrm{~cm})\end{array}$ & $\begin{array}{c}\text { Root } \\
\text { length* } \\
(\mathrm{cm})\end{array}$ & $\begin{array}{c}\text { Germinat- } \\
\text { ion*\% }\end{array}$ & $\begin{array}{c}\text { Shoot } \\
\text { length* } \\
(\mathrm{cm})\end{array}$ & $\begin{array}{c}\text { Root } \\
\text { length* } \\
(\mathrm{cm})\end{array}$ & $\begin{array}{c}\text { Germi } \\
\text { nat- } \\
\text { ion* } \\
\%\end{array}$ & $\begin{array}{c}\text { Shoot } \\
\text { length* } \\
(\mathrm{cm})\end{array}$ & $\begin{array}{c}\text { Root } \\
\text { length* } \\
(\mathrm{cm})\end{array}$ \\
\hline $\begin{array}{l}\text { Azadirachta } \\
\text { indica (Neem) }\end{array}$ & 71 & 3.95 & 4.22 & 79 & 4.08 & 4.49 & 85 & 4.18 & 4.62 \\
\hline $\begin{array}{l}\text { Allium } \\
\text { sativum } \\
\text { (Garlic) }\end{array}$ & 56 & 2.26 & 4.36 & 63 & 2.48 & 4.53 & 72 & 2.76 & 4.64 \\
\hline $\begin{array}{l}\text { Zingiber } \\
\text { officinale } \\
\text { (Ginger) }\end{array}$ & 75 & 9.26 & 6.99 & 81 & 9.41 & 7.09 & 88 & 9.78 & 7.19 \\
\hline Control & 64 & 3.78 & 3.30 & 64 & 3.78 & 3.30 & 64 & 3.78 & 3.30 \\
\hline CD(5\%) & $\mathbf{4 . 8 1}$ & $\mathbf{0 . 3 1}$ & $\mathbf{0 . 2 0}$ & $\mathbf{4 . 5 4}$ & $\mathbf{0 . 3 0}$ & $\mathbf{0 . 1 5}$ & $\mathbf{4 . 4 0}$ & $\mathbf{0 . 1 9}$ & $\mathbf{0 . 1 1}$ \\
\hline CV\% & $\mathbf{1 0 . 9 9}$ & $\mathbf{4 . 8 0}$ & $\mathbf{3 . 2 3}$ & $\mathbf{1 0 . 6 8}$ & $\mathbf{0 . 3 3}$ & $\mathbf{2 . 3 6}$ & $\mathbf{9 . 8 1}$ & $\mathbf{2 . 8 5}$ & $\mathbf{1 . 7 1}$ \\
\hline
\end{tabular}


Fig.1 Effect of plant extracts as seed treatment on seed germination of Rice

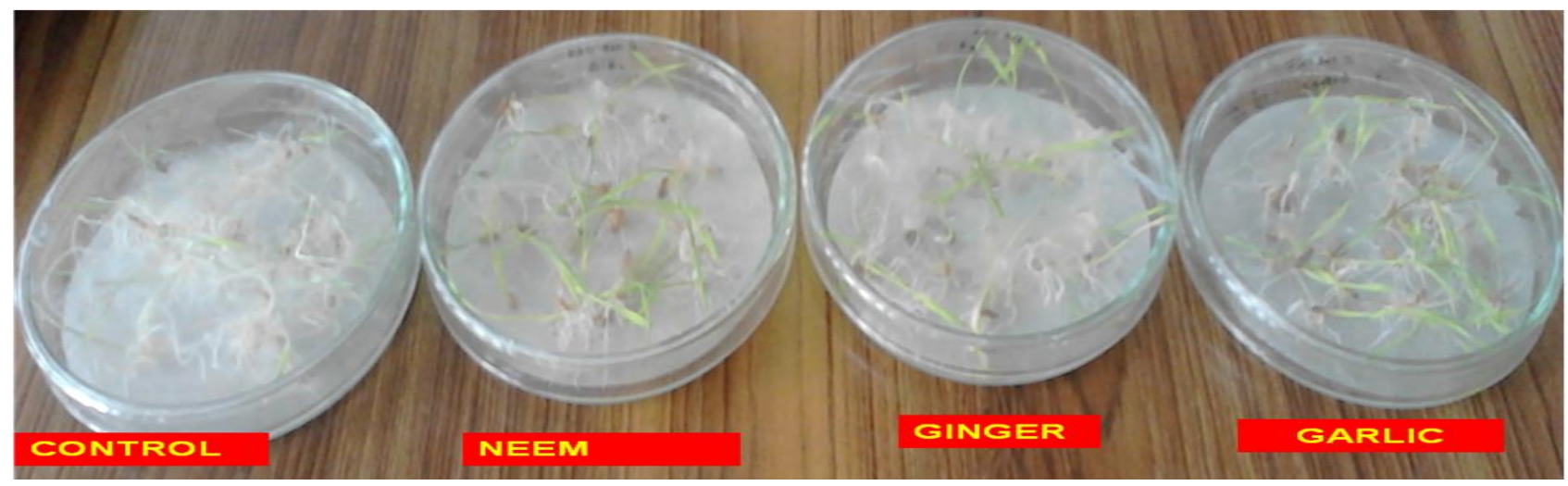

Fig.2 Effect of chemicals as seed treatment on seed germination of rice

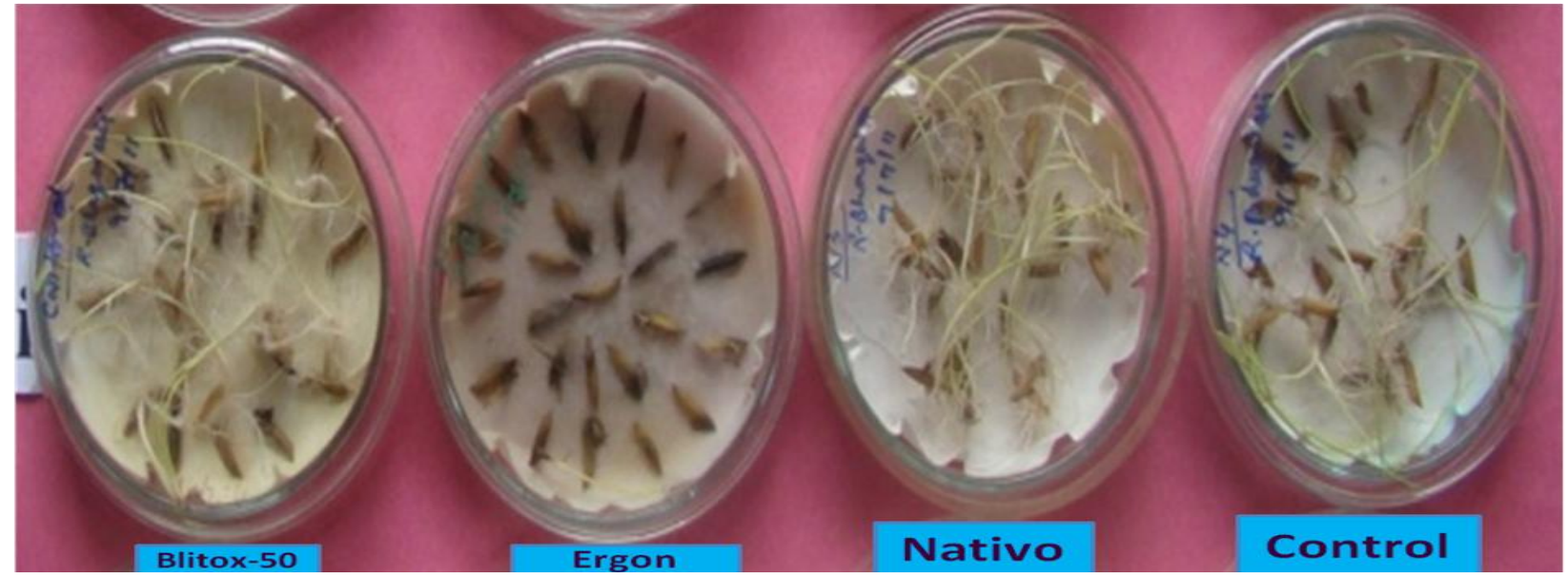

Effect of seed treatment with new chemicals on seed germination

In respect to new chemicals, for better germination was recorded seed treatment with Blitox-50 +Streptocycline, Nativo 75WG and Ergon 44.3 SC effective against the BLB pathogen were tested for seed germination of rice through seed treatment on variety i.e. Pusa Basmati @ 10ppm, 25ppm and 50ppm. New chemicals were increased the shoot length of rice varieties. It also enhanced the root and shoot length in rice variety i.e. Pusa Basmati seed treatment with new chemicals i.e. Blitox-50 +Streptocycline (88\%), Nativo 75WG (80\%) and Ergon 44.3 SC (72\%) @ 50 ppm conc.that effective against the BLB pathogen enhanced the seed germination as compare to control.
Present finding also similar with the findings of Patel et al., (2009), Munna et al., (2004) and Thimmegowda et al., (2005). They also reported the Blitox-50+ streptocycline, increasing grain and inhibitory effect against Xathomonas oryzae pv. oryzae.

So, Seed treatment with botanical and new chemicals viz: Zingiber officinale, Azadirachta indica Blitox-50 +Streptocycline (88\%), Nativo $75 \mathrm{WG}$ respectively isolates was effective in increasing seed germination and seed germination of Pusa Basmati rice variety as compare to control. So, those two botanicals as well as two new chemicals were used for further studies in field conditions.

It is concluded in present investigation, all the tested botanical and new chemical isolated 
again Xanthomonas oryazae pv. oryzae, The aqueous leaf extract of botanicals were effective i.e., Allium sativum, Azadirachta indica and Zingiber officinale were found to be antagonistic towards Xanthomonas oryzae pv.oryzae@15\% concentration after 48 hours. Three chemicals found effective in reducing severity of BLB were Blitox50+Streptocycline; Ergon 44.3 SC and Nativo 75WG @50 ppm concentration showed inhibition colony width growth of pathogen by poisons food technique respectively. The seed treatment with six effective i.e. three botanical and three new chemical provide good protection of seed against seed borne pathogen resulting increase seed germination and seedling vigor of rice variety as compare to control.

\section{References}

Biswas, S.K., Ratan, V., Srivastava, S.L. and Yadav, R. 2008. Influuence of seed treatment with biocides and foliar spray with fungicides for management of brown leaf spot and sheath blight of paddy. Indian Phytopath., 61(1): 55-59.

Kagle, S., Marimuthu, T, Thayumanavan, B., Nandakumar, R., Samiyappan, R. 2004. Antibacterial activity and induction of systemic resistance in rice by leaf extract of datura metel against Rhizoctonia solani and Xanthomona oryzae pv.oryzae. Physiol. Mol. Plant Pathol., 65: 91-100.

Kumar, M., Parate, R.L., and Ninawe, B.N. 2009. Effect of botanicals, bioagents and some chemicals against Xathomonas oryzae pv. oryzae. J. Plant Dis. Sci., 4(1): 60-63.

Manav, M. and Thind, B.S. 2002. Management of bacterial blight of rice with bioagents. $\mathrm{Pl}$.
Dis. Res., 17: 21-28.

Narasimhan, V., Selvam, R. and Mariappan, V. 1995. In Mariappan V(editor). Neem for the management of crop diseases. Associated Publishing Co. New Delhi: pp 15 - 121.

Patel, S.J., Chauhan, H.L., Mehta, A.N. and Gohil, N.M. 2009. Management of bacterial blight of rice with chemicals, botanicals and antagonists. J. Plant Dis. Sci., 4(2): 208211

Sen, B. 1999. Kalisena an ecofriendly biopestcide cum - biofertilizer from Aspergillus niger AN 27. Division of Plant Pathology, IARI, New Delhi, pp 10.

Singh, V., Kumar, R., Singh, G. and Prasad, C.S. 2010. Management of sheath blight of rice with integration of Trichoderma harzianum and Pseudomonas fluorescens. Ann. Pl. Protec. Sci., 18: 156-158

Srinivasan, M. C., Thirumalachar, M.J. and Patel, M.K. 1990. Bacterial blight disease of rice. Curr. Sci., 28: 469.

Sunder, S., Singh, R. and Dodan, D.S. 2005. Management of bacterial blight of rice with botanical extracts and non-conventional chemicals; J. Plant Dis. Res., 20(1): 12-17.

Swing, J.M., Mooter, V., Vauterin, L, Hoste, B., Gills, M., Mew, T.W. and Kersters K. 1990. Reclassification of the causal agents of bacterial blight (Xanthomonas campestris $p v$. oryzae) and bacterial leaf streak (Xanthomonas campestris pv. oryzicola) of rice pathovars of Xanthomonas oryzae (ex Ishiyama, 1992) sp. Nov., nom. Rev. Int. J. Systematic Bacteriol., 40: 309-311.

Thimmegowda, P.R., Sataraddi, A., Ambika, D.S., Prasad, P.S. and Chandrasekhar, M. 2012. Efficacy of antibiotics and biorational pesticides against bacterial blight of paddy; Madras Agri. J., 99(7-9): 592-596.

\section{How to cite this article:}

Archana Bala, Bimla Rai, Sweta Priya and Rahul Kumar. 2017. In vitro Evaluation of Various Fungicides and Plant Extracts against Xanthomonas oryazae pv. oryzae Isolated from Rice (Oryza sativa L.). Int.J.Curr.Microbiol.App.Sci. 6(5): 421-427.

doi: http://dx.doi.org/10.20546/ijcmas.2017.605.048 